\title{
Effects of different forage:concentrate ratios in dairy ewe diets supplemented with sunflower oil on animal performance and milk fatty acid profile
}

\author{
P. Gómez-Cortés, ${ }^{1}{ }^{1} M$. A. de la Fuente, ${ }^{\star}$ P. G. Toral,$\dagger^{2}$ P. Frutos, $\nmid$ M. Juárez, ${ }^{\star}$ and G. Hervás† \\ *Instituto de Investigación en Ciencias de la Alimentación (CSIC-UAM), Nicolás Cabrera, 9, Universidad Autónoma de Madrid, 28049 Madrid, \\ Spain \\ †Instituto de Ganadería de Montaña (CSIC-ULE), Finca Marzanas s/n. 24346 Grulleros, León, Spain
}

\begin{abstract}
The aim of this study was to evaluate the effect of different forage:concentrate $(\mathrm{FC})$ ratios in dairy ewe diets supplemented with sunflower oil (SO) on animal performance and milk fatty acid (FA) profile, particularly focusing on trans C18:1 FA and conjugated linoleic acid (CLA). Sixty lactating Assaf ewes were randomly assigned to 6 treatments in a $3 \times 2$ factorial arrangement: $3 \mathrm{FC}$ ratios (30:70, 50:50, and 70:30) and 2 levels of SO addition (0 and $20 \mathrm{~g} / \mathrm{kg}$ of dry matter). Both the diet FC ratio and $\mathrm{SO}$ supplementation affected milk yield, but differences between treatments were small. Although the proportion of concentrate induced limited changes in milk FA profile, dietary SO significantly decreased saturated FA and enhanced total CLA. Furthermore, the incorporation of SO in ewe diets decreased the atherogenicity index value by about $25 \%$ and doubled the contents of potentially healthy FA such as trans-11 C18:1 and cis-9,trans-11 CLA. However, the inclusion of $\mathrm{SO}$ in a high-concentrate diet (30:70) could switch linoleic acid biohydrogenation pathways, resulting in a significant increase in trans-10 C18:1, trans-9,cis-11 C18:2, and trans-10,cis-12 C18:2 milk fat percentages.
\end{abstract}

Key words: conjugated linoleic acid, basal diet, sheep, trans fatty acid

\section{INTRODUCTION}

Diet is known to strongly influence both milk fat concentration and composition; therefore, many studies have been performed in ruminants to ascertain the effect of different dietary regimens on overall fat content as well as on the milk fatty acid (FA) profile (Chilliard et al., 2007; Shingfield et al., 2008). The FA

\footnotetext{
Received September 9, 2010.

Accepted May 16, 2011.

${ }^{1}$ Current address: Division of Nutritional Sciences, Cornell University, Ithaca, NY 14853.

${ }^{2}$ Corresponding author: pg.toral@eae.csic.es
}

composition of ruminant fats is mostly determined by complex interactions between dietary factors and rumen metabolism. Varying the amount and type of lipid supplementation in ruminant diets is an efficient way of modifying the FA composition of milk. However, biohydrogenation of dietary FA could also be modulated by other factors such as the basal diet composition, resulting in differences in the quantity of unsaturated FA that escape from the rumen (Chilliard and Ferlay, 2004; Palmquist et al., 2005).

In dairy cows, feeding high-concentrate diets and plant oils often decreases milk fat production (Doreau et al., 1999) and increases the concentration of rumenic acid (RA; cis-9,trans-11 C18:2), a conjugated linoleic acid (CLA) isomer with advantageous physiological effects (Lock et al., 2009). In dairy ewes, however, the effect of the forage:concentrate (FC) ratio of the diet on milk composition and the FA profile has been less studied and could offer different results from those reported for other ruminants. In fact, changes in milk yield and fat and protein contents as well as the FA profile in response to a variety of diets and lipid supplements differ greatly from one species to another (Chilliard et al., 2003; Pulina et al., 2006), even among small ruminants (Sanz-Sampelayo et al., 2007; Tsiplakou and Zervas, 2008). A couple of studies (Antongiovanni et al., 2004; Mele et al., 2006) examined the effects of 2 FC ratios (75:25 and 60:40) with and without soybean oil supplementation on ewe milk composition. Interactions between forage and oil resulted in a greater increase in RA and its precursor, vaccenic acid (VA; trans-11 C18:1), when soybean oil was added to a $75: 25$ FC ratio diet. In contrast, trans-10 C18:1 levels were higher when the FC ratio of the diet was 60:40, which was attributed to a shift in the rumen biohydrogenation of linoleic acid. Data from more recent works also suggest that increases in trans-10 C18:1 content with sunflower oil (SO) supplementation could be related to the FC ratio (Toral et al., 2010a,b).

The scarcity, as well as the heterogeneity of most of the published studies on this issue, makes it difficult to establish an appropriate FC ratio in dairy ewe oil-sup- 
plemented diets to obtain a healthier milk FA composition for human consumers, with no detrimental effects on animal performance. Consequently, the purpose of this study was to investigate the effect of $3 \mathrm{FC}$ ratios in SO-supplemented diets on dairy ewe performance and the milk FA profile. A further objective was to examine the evolution of the response over a 4 -wk period.

\section{MATERIALS AND METHODS}

\section{Animals, Experimental Diets, and Management}

Sixty multiparous Assaf ewes at wk 6 of lactation were distributed in 12 lots of 5 animals each, balanced for milk production $(3.17 \mathrm{~kg} / \mathrm{d}$; $\mathrm{SD}=1.054)$, $\mathrm{BW}(83.1$; $\mathrm{SD}=12.62$ ), days postpartum (43 at the beginning of the experiment; $\mathrm{SD}=7.1$ ), and lactation number $(3.7 ; \mathrm{SD}=0.65)$. The lots were randomly assigned to 6 treatments ( 2 lots per treatment) in a $3 \times 2$ factorial arrangement: $3 \mathrm{FC}$ ratios (30:70, 50:50, and 70:30) and 2 levels of SO addition, $0(\mathbf{C})$ and $20 \mathrm{~g} / \mathrm{kg}$ of DM (SO).
Before starting the experiment, all sheep were fed diets without oil for a 7-d adaptation period and then treatments (C 30:70, C 50:50, C 70:30, SO 30:70, SO 50:50, and SO 70:30) were begun and lasted for $4 \mathrm{wk}$.

The ingredients and chemical composition of the 6 experimental diets are given in Table 1 . Clean water was always available and fresh diets were offered ad libitum at 0900 and $1900 \mathrm{~h}$ daily. The ewes were milked at approximately 0830 and $1830 \mathrm{~h}$ in a $1 \times 10$ stallmilking parlor (DeLaval, Madrid, Spain). The experiment was carried out in accordance with the Spanish Royal Decree 1201/2005 for the protection of animals used for experimental purposes.

\section{Measurements, Sample Collection, and Chemical Analyses}

Samples of offered and refused diets were collected once a week, stored at $-30^{\circ} \mathrm{C}$, and then freeze-dried. The DMI was recorded weekly for each experimental lot. Diet samples were analyzed for DM (ISO 6496;

Table 1. Ingredients, chemical composition, and fatty acid (FA) profile of the experimental diets ${ }^{1}$

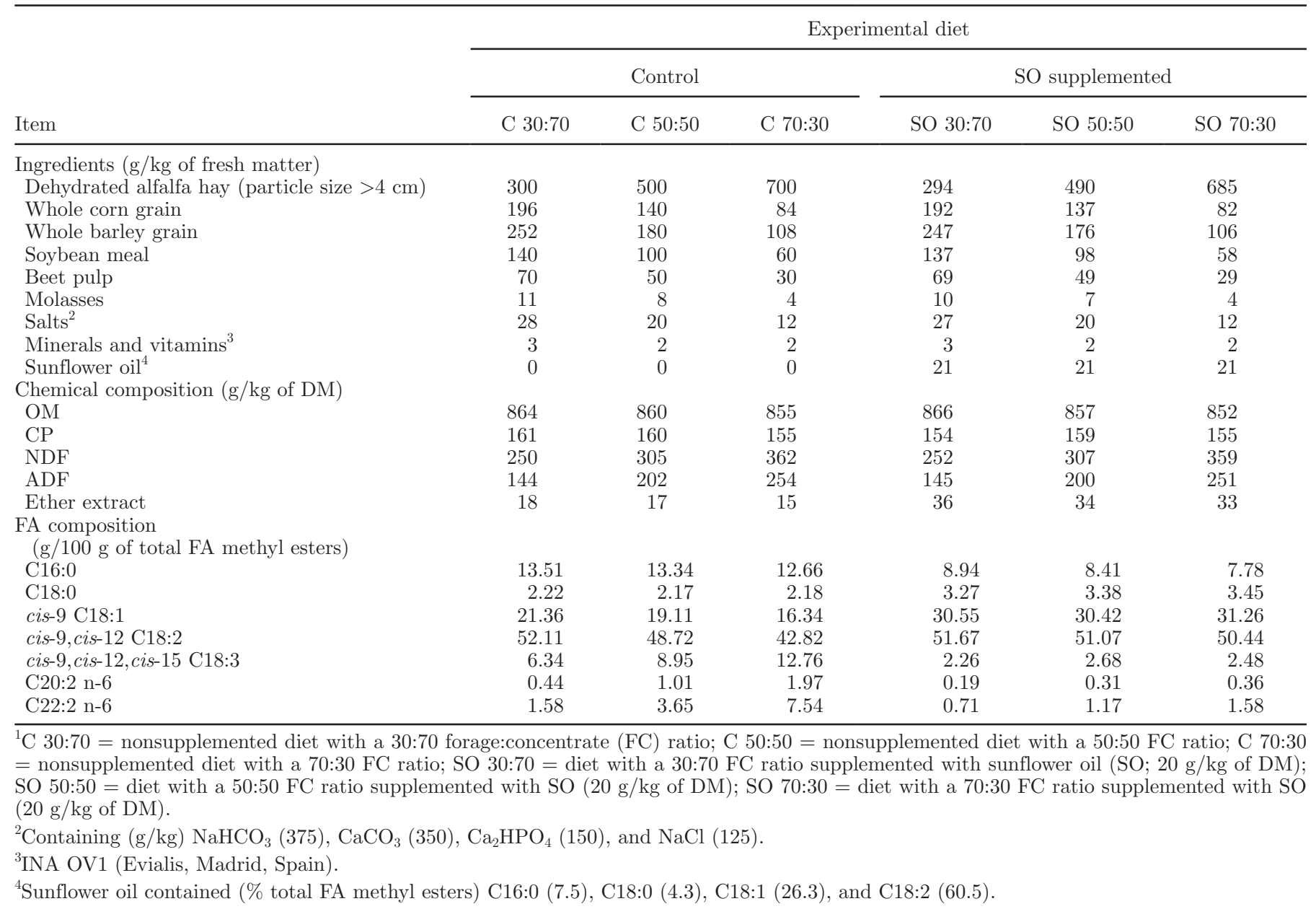


ISO, 1999a), ash (ISO 5984; ISO, 2002a) and CP (ISO 5983-2; ISO, 2005). Neutral detergent fiber and ADF were determined as described by Ankom Technology (Macedon, NY). Neutral detergent fiber was assayed with sodium sulfite and $\alpha$-amylase and expressed with residual ash (the latter also for ADF). Ether extract content in the diets was determined using Ankom Filter Bag Technology (American Oil Chemists' Society Official Procedure Am 5-04; AOCS, 2008).

Individual milk yield was recorded on d $0,3,7,14$, 21 , and 28 , at both the morning and evening milkings. With the same frequency, milk samples for the analysis of fat, protein, and TS were collected from each animal and treated with natamycin. The protein, fat, and TS concentrations were determined by infrared spectrophotometry (ISO 9622; ISO, 1999b), using a Milko-Scan 255 A/S N (Foss Electric, Hillerød, Denmark).

Milk FA composition was also determined on d 0 , $3,7,14,21$, and 28 , in untreated samples from each experimental lot, composited according to individual milk production. Milk fat was extracted as described by Luna et al. (2005), and fatty acid methyl esters (FAME) were prepared by base-catalyzed methanolysis of the glycerides (ISO 15884; ISO, 2002b). Analysis of FAME in hexane was carried out on a gas chromatograph (Agilent 6890 N Network System, Palo Alto, CA) with auto injector and fitted with a flame-ionization detector. The FAME profile was determined by split injection (1:100) onto a CP-Sil 88 fused-silica capillary column $(100 \mathrm{~m} \times 0.25 \mathrm{~mm}$ i.d., $0.20-\mu \mathrm{m}$ film thickness; Varian, Middelburg, the Netherlands) using a gradient temperature program. The initial oven temperature was $160^{\circ} \mathrm{C}$. After $80 \mathrm{~min}$, it was increased at $10^{\circ} \mathrm{C} / \mathrm{min}$ to $210^{\circ} \mathrm{C}$ and then held for $35 \mathrm{~min}$. Helium was the carrier gas and the injector and detector were at $250^{\circ} \mathrm{C}$.

Separation of CLA methyl esters was also carried out in samples obtained at $0,7,21$, and $28 \mathrm{~d}$ using an HPLC (model SPE-MA10AVP, Shimadzu, Kyoto, Japan) equipped with a diode array detector operated at $233 \mathrm{~nm}$. Three ChromSpher 5 Lipids analytical silverimpregnated columns $(250 \mathrm{~mm} \times 4.6 \mathrm{~mm}$ i.d. stainless steel; 5 - $\mu \mathrm{m}$ particle size; Varian) were used in series. The mobile phase of $0.1 \%$ acetonitrile and $0.5 \%$ diethyl ether in hexane was operated isocratically at a flow rate of $1.0 \mathrm{~mL} / \mathrm{min}$. The chromatographic areas for $7-9$, 8-10, and 9-11 CLA were used for comparison with the peak area of the 3 isomers from the gas chromatogram.

\section{Statistical Analyses}

All analyses were performed using the SAS software package, version 9.1 (SAS Institute Inc., Cary, NC). Data on DMI, milk yield, and milk composition, as well as FA composition, were analyzed by repeated mea- surement analysis, using the MIXED procedure and assuming a covariance structure based on the Schwarz's Bayesian information model fit criterion. The statistical model included the fixed effects of oil supplementation $(\mathrm{SO}), \mathrm{FC}$ ratio of the diet $(\mathrm{FC})$, time $(\mathbf{T})$, their interactions $(\mathrm{SO} \times \mathrm{FC}, \mathrm{SO} \times \mathrm{T}, \mathrm{FC} \times \mathrm{T}$, and $\mathrm{SO} \times \mathrm{FC} \times$ $\mathrm{T})$, and the initial record measured at 0 wk (covariate). Because the effects of interactions with time (i.e., $\mathrm{SO} \times$ $\mathrm{T}, \mathrm{FC} \times \mathrm{T}$, and $\mathrm{SO} \times \mathrm{FC} \times \mathrm{T})$ were seldom significant for the parameters studied (both for animal performance and milk FA profile), they were not included in the tables. For all data collected either individually (milk yield and composition) or per lot (DMI and FA composition), lot was nested within diet to contrast the effect of the lipid supplementation and the FC ratio. Pearson correlation coefficients ( $\mathrm{r}$ ) were generated using the CORR procedure. Significant differences were declared at $P<0.05$ and tendencies accepted if $P<$ 0.10 . Least squares means (adjusted for the covariance) are reported throughout.

\section{RESULTS AND DISCUSSION}

\section{Ewe Performance and Milk Composition}

As shown in Table 2, milk yield was affected by both the FC ratio and SO supplementation, with a significant interaction effect $(P<0.01)$, although variations between experimental diets were small. In this regard, the largest difference $(-11 \%)$ was observed between the mean milk yield from treatment SO $30: 70(2.4 \mathrm{~kg} / \mathrm{d})$ and that from C 70:30 and SO 50:50 $(2.7 \mathrm{~kg} / \mathrm{d})$. In all cases, maximum yields were observed at the start of the experiment, which then decreased slightly over time ( $P$ $<0.001)$.

Previous research has shown that diet supplementation with linoleic-rich plant oils does not negatively affect DMI in dairy ewes (Mele et al., 2006; Hervás et al., 2008; Toral et al., 2010a). In the current study, a small increase in feed consumption was observed in response to the addition of $2 \%$ of $\mathrm{SO}$ in the diet $(P<$ $0.05)$, whereas intake was not significantly affected by the FC ratio, tending to increase only slightly $(+6 \% ; P$ $<0.10$ ) with the inclusion of higher forage proportions in the diet. In farms of northwestern Spain, average values of feeding allowance offered to Assaf dairy ewes in early and mid lactation range between 3.2 and 3.3 $\mathrm{kg} / \mathrm{d}$, with mean FC ratios of 42:58 (Milán et al., 2011). Feed consumption was, in any case, rather high for the 6 diets tested and ranged between 3.3 and $3.8 \mathrm{~kg}$ per animal and day (approximately $4.25 \%$ on a BW basis). Thus, the high levels of intake could have contributed to achieving the potential milk production capability in ewes from all treatments, in spite of the different 
Table 2. Effect of sunflower oil supplementation (SO), FC ration of the diet $(\mathrm{FC})$, their interaction $(\mathrm{SO} \times \mathrm{FC})$, and time $(\mathrm{T})$ on $\mathrm{DMI}$, milk yield, and milk composition in dairy ewes

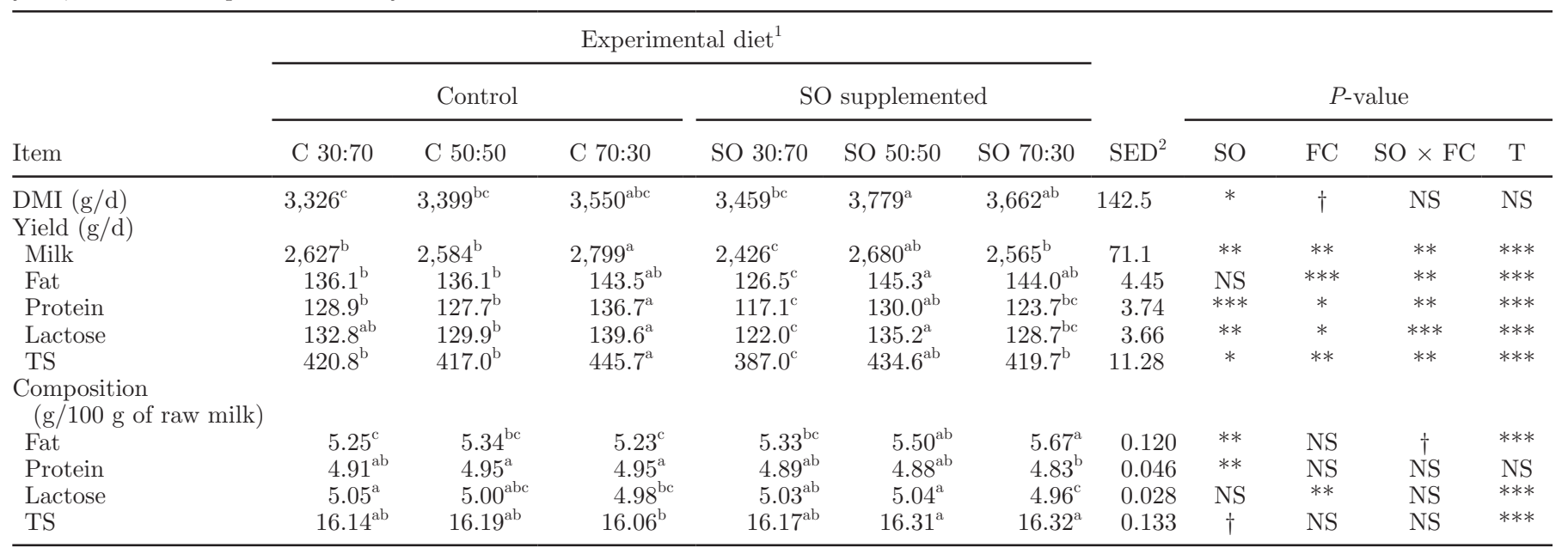

${ }^{\mathrm{a}-\mathrm{c}}$ Means within a row with different superscripts differ significantly.

${ }^{1} \mathrm{C}$ 30:70 = nonsupplemented diet with a 30:70 forage:concentrate (FC) ratio; C 50:50 = nonsupplemented diet with a 50:50 FC ratio; C 70:30 $=$ nonsupplemented diet with a 70:30 FC ratio; SO 30:70 = diet with a 30:70 FC ratio supplemented with sunflower oil (SO; $20 \mathrm{~g} / \mathrm{kg}$ of DM); SO 50:50 = diet with a 50:50 FC ratio supplemented with SO $(20 \mathrm{~g} / \mathrm{kg}$ of DM); SO 70:30 = diet with a 70:30 FC ratio supplemented with SO $(20 \mathrm{~g} / \mathrm{kg}$ of DM).

${ }^{2} \mathrm{SED}=$ standard error of the difference.

$\dagger P<0.10 ;{ }^{*} P<0.05 ;{ }^{* *} P<0.01 ;{ }^{* * *} P<0.001 ; \mathrm{NS}=P>0.10$.

FC ratios of the experimental diets and the high milk yields.

As in other dairy species, milk yield and milk fat and protein contents are negatively correlated in sheep (Bocquier and Caja, 2001). In contrast, milk fat and dietary NDF concentrations would be positively correlated in highly productive dairy ewes, in a similar manner as seen in cows (Pulina et al., 2006). In this experiment, however, the NDF level had no evident effect on milk fat and protein composition, which may be because a large part of that potentially positive effect of dietary fiber on milk fat content has been related to its negative effect on milk yield (Pulina et al., 2006). By contrast, supplementation with SO would explain the major changes in milk composition; that is, a slight decrease in the protein content $(-1.4 \%)$ and a higher fat content (4.4\%). These observations are in general agreement with previous studies in highly productive dairy ewes fed SO-supplemented diets (Hervás et al., 2008; Toral et al., 2010a,b).

\section{Saturated FA}

The effects of dietary treatments on milk FA composition are presented in Table 3. In general, most FA were affected by SO supplementation or the ewe basal diet composition. Taken as a whole, saturated FA, which make up the principal group, were significantly affected $(P<0.001)$ not only by the FC ratio but more so by SO supplementation. However, the behavior of individual saturated FA differed and a variety of trends was observed in the current study. The proportion of forage did not significantly affect $\mathrm{C} 4: 0$ percentages but this FA was slightly reduced with SO 30:70. Ewes fed the high-concentrate diet (C 30:70) produced milk containing a lower amount of $\mathrm{C} 12: 0$ and $\mathrm{C} 16: 0$ than ewes on the $\mathrm{C}$ 70:30 treatment, whereas other saturated FA, such as C10:0 and C14:0, were increased proportionally to the level of concentrate in the ration $(P<0.001$; Table 3). However, regardless of the FC ratio, concentrations of most of these even-numbered FA from C10:0 to $\mathrm{C} 16: 0$ were lower in SO-supplemented rations (Table $3)$.

Increases of medium-chain saturated FA in animals fed higher proportions of concentrate have already been reported in cow (Bargo et al., 2006), goat (Tsiplakou and Zervas, 2008), and ewe (Mele et al., 2006; Martini et al., 2010) milk fat. Furthermore, the abundance of unsaturated C18 FA in SO (Table 1) would explain the results (Table 3) in SO-supplemented diets. These FA or their intermediates produced during rumen biohydrogenation (see below) are potent inhibitors of de novo FA synthesis in the mammary gland and could bring about a relative decrease in short- and mediumchain FA, which would be compensated by an increase in the levels of C18 FA (Chilliard and Ferlay, 2004) milk fat content, as was formerly observed in dairy ewes fed the same lipid source (Hervás et al., 2008; Toral et 
Table 3. Effect of sunflower oil supplementation (SO), FC ratio of the diet (FC), their interaction $(\mathrm{SO} \times \mathrm{FC})$, and time $(\mathrm{T})$ on milk fatty acid (FA) profile determined by gas chromatography in dairy ewes

\begin{tabular}{|c|c|c|c|c|c|c|c|c|c|c|c|}
\hline \multirow{2}{*}{$\begin{array}{l}\text { FA ( } \mathrm{g} / 100 \mathrm{~g} \text { of total } \\
\text { FA methyl esters) }\end{array}$} & \multicolumn{6}{|c|}{ Experimental $\operatorname{diet}^{1}$} & \multirow{2}{*}{$\mathrm{SED}^{2}$} & \multirow{2}{*}{\multicolumn{4}{|c|}{$P$-value }} \\
\hline & \multicolumn{3}{|c|}{ Control } & \multicolumn{3}{|c|}{ SO supplemented } & & & & & \\
\hline \multicolumn{12}{|l|}{ Saturated } \\
\hline $\mathrm{C} 4: 0$ & $4.19^{\mathrm{a}}$ & $4.23^{\mathrm{a}}$ & $4.19^{\mathrm{a}}$ & $4.03^{\mathrm{b}}$ & $4.15^{\mathrm{ab}}$ & $4.13^{\mathrm{ab}}$ & 0.810 & * & NS & NS & $* * *$ \\
\hline C10:0 & $12.15^{\mathrm{a}}$ & $10.74^{\mathrm{c}}$ & $9.65^{\mathrm{d}}$ & $11.41^{\mathrm{b}}$ & $9.79^{\mathrm{d}}$ & $8.00^{\mathrm{e}}$ & 0.200 & $* * *$ & $* * *$ & $* *$ & $* * *$ \\
\hline C12:0 & $5.26^{\mathrm{d}}$ & $5.52^{\mathrm{cd}}$ & $6.21^{\mathrm{a}}$ & $5.54^{\mathrm{cd}}$ & $6.00^{\mathrm{ab}}$ & $5.75^{\mathrm{bc}}$ & 0.254 & NS & $* * *$ & $* * *$ & $* * *$ \\
\hline $\mathrm{C} 13: 0$ iso & $0.01^{\mathrm{b}}$ & $0.01^{\mathrm{b}}$ & $0.02^{\mathrm{a}}$ & $0.01^{\mathrm{b}}$ & $0.01^{\mathrm{b}}$ & $0.02^{\mathrm{a}}$ & 0.001 & NS & $* * *$ & NS & NS \\
\hline $\mathrm{C} 13: 0$ anteiso & $0.06^{\mathrm{a}}$ & $0.06^{\mathrm{a}}$ & $0.05^{\mathrm{b}}$ & $0.06^{\mathrm{a}}$ & $0.04^{\mathrm{b}}$ & $0.03^{\mathrm{c}}$ & 0.003 & $* * *$ & $* * *$ & $* *$ & NS \\
\hline C13:0 & $0.16^{\mathrm{b}}$ & $0.17^{\mathrm{b}}$ & $0.20^{\mathrm{a}}$ & $0.17^{\mathrm{b}}$ & $0.20^{\mathrm{a}}$ & $0.17^{\mathrm{b}}$ & 0.011 & NS & $* *$ & $* * *$ & $* * *$ \\
\hline $\mathrm{C} 14: 0$ iso & $0.09^{\text {cd }}$ & $0.12^{\mathrm{b}}$ & $0.15^{\mathrm{a}}$ & $0.08^{\mathrm{d}}$ & $0.10^{\mathrm{c}}$ & $0.13^{\mathrm{b}}$ & 0.007 & $* * *$ & $* * *$ & NS & NS \\
\hline $\mathrm{C} 14: 0$ & $12.22^{\mathrm{a}}$ & $11.53^{\mathrm{b}}$ & $10.88^{\mathrm{c}}$ & $11.90^{\mathrm{ab}}$ & $10.26^{\mathrm{d}}$ & $10.00^{\mathrm{d}}$ & 0.192 & $* * *$ & $* * *$ & $* *$ & $*$ \\
\hline C17:0 & $0.45^{\mathrm{c}}$ & $0.49^{\mathrm{bc}}$ & $0.51^{\mathrm{ab}}$ & $0.48^{\mathrm{bc}}$ & $0.54^{\mathrm{a}}$ & $0.46^{\mathrm{c}}$ & 0.023 & NS & $* *$ & $* *$ & $* * *$ \\
\hline $\mathrm{C} 18: 0$ iso & $0.06^{\mathrm{c}}$ & $0.06^{\mathrm{bc}}$ & $0.07^{\mathrm{a}}$ & $0.07^{\mathrm{a}}$ & $0.06^{\mathrm{bc}}$ & $0.06^{\mathrm{b}}$ & 0.004 & NS & $*$ & $* *$ & $* * *$ \\
\hline C18:0 & $5.92^{\mathrm{d}}$ & $6.76^{\mathrm{c}}$ & $6.75^{\mathrm{c}}$ & $6.54^{\mathrm{c}}$ & $8.42^{\mathrm{b}}$ & $9.50^{\mathrm{a}}$ & 0.197 & $* * *$ & $* * *$ & $* * *$ & $* * *$ \\
\hline C20:0 & $0.13^{\mathrm{d}}$ & $0.18^{\mathrm{c}}$ & $0.19^{\mathrm{b}}$ & $0.13^{\mathrm{d}}$ & $0.18^{\mathrm{c}}$ & $0.21^{\mathrm{a}}$ & 0.004 & $* * *$ & $* * *$ & $* *$ & $* * *$ \\
\hline $\mathrm{C} 21: 0$ & $0.06^{\mathrm{ab}}$ & $0.06^{\mathrm{a}}$ & $0.05^{\mathrm{b}}$ & $0.05^{\mathrm{ab}}$ & $0.05^{\mathrm{ab}}$ & $0.05^{\mathrm{b}}$ & 0.004 & NS & $\dagger$ & NS & $* * *$ \\
\hline $\mathrm{C} 22: 0$ & $0.06^{\mathrm{e}}$ & $0.09^{\mathrm{c}}$ & $0.11^{\mathrm{b}}$ & $0.07^{\mathrm{d}}$ & $0.11^{\mathrm{b}}$ & $0.14^{\mathrm{a}}$ & 0.003 & $* * *$ & $* * *$ & $\dagger$ & $* * *$ \\
\hline $\mathrm{C} 23: 0$ & $0.05^{\mathrm{bc}}$ & $0.04^{\mathrm{c}}$ & $0.05^{\mathrm{bc}}$ & $0.05^{\mathrm{b}}$ & $0.07^{\mathrm{a}}$ & $0.04^{\mathrm{c}}$ & 0.004 & $* *$ & $* *$ & $* * *$ & $* * *$ \\
\hline C24:0 & $0.02^{\mathrm{c}}$ & $0.04^{\mathrm{b}}$ & $0.05^{\mathrm{a}}$ & $0.02^{\mathrm{c}}$ & $0.04^{\mathrm{b}}$ & $0.05^{\mathrm{a}}$ & 0.003 & NS & $* * *$ & NS & NS \\
\hline \multicolumn{12}{|l|}{ Monounsaturated } \\
\hline C10:1 & $0.38^{\mathrm{c}}$ & $0.40^{\mathrm{bc}}$ & $0.42^{\mathrm{ab}}$ & $0.40^{\mathrm{bc}}$ & $0.45^{\mathrm{a}}$ & $0.38^{\mathrm{c}}$ & 0.017 & NS & $* *$ & $* * *$ & $* * *$ \\
\hline cis-9 C14:1 & $0.18^{\mathrm{ab}}$ & $0.17^{\mathrm{bc}}$ & $0.16^{\mathrm{c}}$ & $0.20^{\mathrm{a}}$ & $0.14^{\mathrm{d}}$ & $0.13^{\mathrm{d}}$ & 0.009 & $* *$ & $* * *$ & $* * *$ & $* *$ \\
\hline $\mathrm{C} 15: 1$ & $0.09^{\mathrm{d}}$ & $0.13^{\mathrm{bc}}$ & $0.15^{\mathrm{a}}$ & $0.08^{\mathrm{d}}$ & $0.12^{\mathrm{c}}$ & $0.14^{\mathrm{ab}}$ & 0.005 & $* *$ & $* * *$ & NS & $*$ \\
\hline trans-8 C16:1 & $0.08^{\mathrm{b}}$ & $0.07^{\mathrm{c}}$ & $0.06^{\mathrm{c}}$ & $0.12^{\mathrm{a}}$ & $0.08^{\mathrm{b}}$ & $0.08^{\mathrm{b}}$ & 0.005 & $* * *$ & $* * *$ & $*$ & $*$ \\
\hline trans-9 C16:1 + C17:0 iso & $0.40^{\mathrm{b}}$ & $0.40^{\mathrm{b}}$ & $0.41^{\mathrm{b}}$ & $0.46^{\mathrm{a}}$ & $0.45^{\mathrm{a}}$ & $0.48^{\mathrm{a}}$ & 0.017 & $* * *$ & NS & NS & NS \\
\hline cis-9 C18:1 & $11.20^{\mathrm{e}}$ & $12.74^{\mathrm{d}}$ & $15.41^{\mathrm{b}}$ & $12.01^{\mathrm{de}}$ & $14.45^{\mathrm{c}}$ & $16.72^{\mathrm{a}}$ & 0.406 & $* * *$ & $* * *$ & NS & $\dagger$ \\
\hline cis- $11+$ trans- $15 \mathrm{C} 18: 1$ & $0.34^{\mathrm{cd}}$ & $0.33^{\mathrm{d}}$ & $0.37^{\mathrm{bc}}$ & $0.36^{\mathrm{bcd}}$ & $0.42^{\mathrm{a}}$ & $0.39^{\mathrm{ab}}$ & 0.018 & $* * *$ & t & $* *$ & $* * *$ \\
\hline cis-12 C18:1 & $0.40^{\mathrm{c}}$ & $0.31^{\mathrm{d}}$ & $0.26^{\mathrm{d}}$ & $0.52^{\mathrm{b}}$ & $0.60^{\mathrm{a}}$ & $0.52^{\mathrm{b}}$ & 0.031 & $* * *$ & $* *$ & $* * *$ & $* * *$ \\
\hline cis-13 C18:1 & $0.06^{\mathrm{b}}$ & $0.05^{\mathrm{c}}$ & $0.05^{\mathrm{c}}$ & $0.07^{\mathrm{a}}$ & $0.06^{\mathrm{b}}$ & $0.05^{\mathrm{c}}$ & 0.003 & $* * *$ & $* * *$ & $*$ & NS \\
\hline cis-14 + trans-16 C18:1 & $0.27^{\mathrm{c}}$ & $0.32^{\mathrm{b}}$ & $0.30^{\mathrm{b}}$ & $0.27^{\mathrm{c}}$ & $0.42^{\mathrm{a}}$ & $0.42^{\mathrm{a}}$ & 0.012 & $* * *$ & $* * *$ & $* * *$ & $* * *$ \\
\hline cis-15 C18:1 & $0.06^{\mathrm{d}}$ & $0.08^{\mathrm{c}}$ & $0.09^{\mathrm{b}}$ & $0.08^{\mathrm{c}}$ & $0.10^{\mathrm{ab}}$ & $0.11^{\mathrm{a}}$ & 0.005 & $* * *$ & $* * *$ & NS & NS \\
\hline cis-16 C18:1 & $0.02^{\mathrm{b}}$ & $0.03^{\mathrm{a}}$ & $0.03^{\mathrm{a}}$ & $0.02^{\mathrm{b}}$ & $0.03^{\mathrm{a}}$ & $0.03^{\mathrm{a}}$ & 0.002 & NS & $* * *$ & NS & NS \\
\hline cis-9 C20:1 & $0.07^{\mathrm{b}}$ & $0.08^{\text {abc }}$ & $0.07^{\mathrm{bc}}$ & $0.08^{\mathrm{bc}}$ & $0.09^{\mathrm{a}}$ & $0.07^{\mathrm{c}}$ & 0.008 & NS & $*$ & $*$ & $* *$ \\
\hline $\mathrm{C} 24: 1$ & $0.02^{\mathrm{b}}$ & $0.02^{\mathrm{b}}$ & $0.03^{\mathrm{a}}$ & $0.02^{\mathrm{b}}$ & $0.02^{\mathrm{b}}$ & $0.02^{\mathrm{b}}$ & 0.002 & NS & NS & NS & $* * *$ \\
\hline \multicolumn{12}{|l|}{ Nonconjugated C18:2 } \\
\hline trans -9, trans -12 & $0.04^{\mathrm{b}}$ & $0.04^{\mathrm{b}}$ & $0.04^{\mathrm{b}}$ & $0.03^{\mathrm{b}}$ & $0.06^{\mathrm{a}}$ & $0.05^{\mathrm{a}}$ & 0.003 & $* * *$ & $* * *$ & $* * *$ & $*$ \\
\hline $\begin{array}{l}\text { trans- } 8, \text { cis- } 12 \\
\quad+\text { cis- } 9, \text { trans }-13\end{array}$ & $0.11^{\mathrm{bc}}$ & $0.14^{\mathrm{a}}$ & $0.10^{\mathrm{c}}$ & $0.14^{\mathrm{a}}$ & $0.11^{\mathrm{bc}}$ & $0.12^{\mathrm{b}}$ & 0.007 & NS & $* *$ & $* * *$ & $* * *$ \\
\hline trans- 8, cis- 13 & $0.06^{\mathrm{c}}$ & $0.08^{\mathrm{b}}$ & $0.08^{\mathrm{ab}}$ & $0.06^{\mathrm{c}}$ & $0.09^{\mathrm{a}}$ & $0.09^{\mathrm{a}}$ & 0.004 & $* *$ & *** & ** & ** \\
\hline trans- 12, cis -9 & $0.03^{\mathrm{b}}$ & $0.03^{\mathrm{b}}$ & $0.03^{\mathrm{b}}$ & $0.03^{\mathrm{b}}$ & $0.04^{\mathrm{a}}$ & $0.04^{\mathrm{a}}$ & 0.003 & $* * *$ & $* *$ & NS & $*$ \\
\hline trans -9, cis -12 & $0.02^{\mathrm{b}}$ & $0.02^{\mathrm{b}}$ & $0.02^{\mathrm{b}}$ & $0.03^{\mathrm{a}}$ & $0.03^{\mathrm{a}}$ & $0.03^{\mathrm{a}}$ & 0.003 & $* * *$ & NS & NS & ** \\
\hline trans- 11, cis- 15 & $0.06^{\mathrm{c}}$ & $0.06^{\mathrm{c}}$ & $0.10^{\mathrm{a}}$ & $0.08^{\mathrm{b}}$ & $0.07^{\mathrm{bc}}$ & $0.09^{\mathrm{ab}}$ & 0.009 & $\dagger$ & $* * *$ & NS & $* * *$ \\
\hline cis- 9, cis- 12 & $2.61^{\mathrm{bc}}$ & $2.55^{\mathrm{cd}}$ & $2.43^{\mathrm{cd}}$ & $2.71^{\mathrm{ab}}$ & $2.80^{\mathrm{a}}$ & $2.41^{\mathrm{d}}$ & 0.183 & $*$ & $* *$ & NS & $* * *$ \\
\hline cis-9,cis-15 & $0.07^{\mathrm{bc}}$ & $0.05^{\mathrm{cd}}$ & $0.09^{\mathrm{a}}$ & $0.04^{\mathrm{d}}$ & $0.07^{\text {abc }}$ & $0.08^{\mathrm{ab}}$ & 0.014 & NS & $* *$ & $*$ & $*$ \\
\hline
\end{tabular}


Table 3 (Continued). Effect of sunflower oil supplementation (SO), FC ratio of the diet (FC), their interaction $(\mathrm{SO} \times \mathrm{FC})$, and time $(\mathrm{T})$ on milk fatty acid (FA) profile determined by gas chromatography in dairy ewes

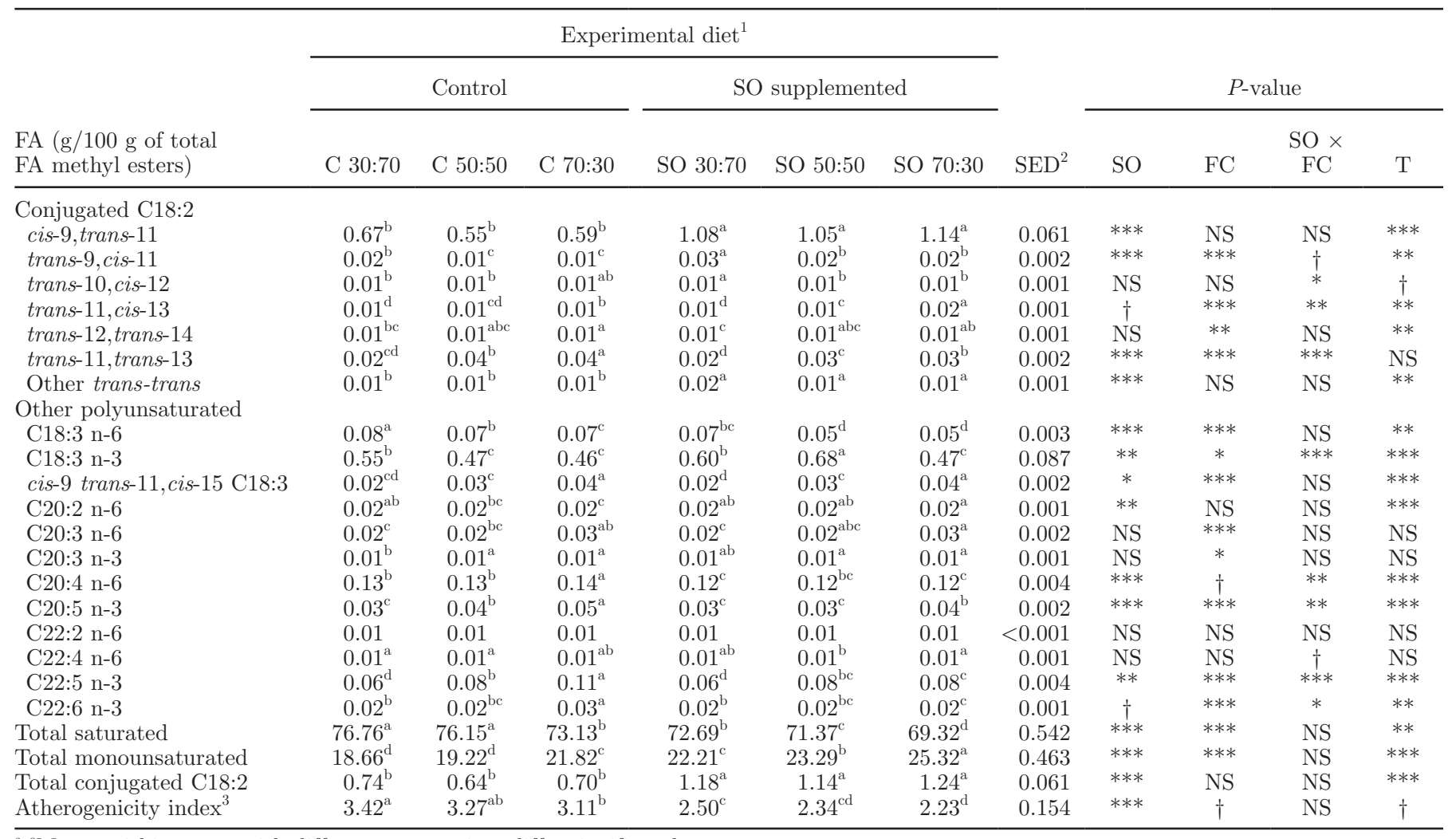

${ }^{\mathrm{a} e}$ Means within a row with different superscripts differ significantly.

${ }^{1} \mathrm{C}$ 30:70 = nonsupplemented diet with a 30:70 forage:concentrate $(\mathrm{FC})$ ratio; $\mathrm{C}$ 50:50 = nonsupplemented diet with a 50:50 FC ratio; C 70:30 $=$ nonsupplemented diet with a 70:30 FC ratio; SO 30:70 = diet with a 30:70 FC ratio supplemented with sunflower oil (SO; $20 \mathrm{~g} / \mathrm{kg}$ of DM); SO 50:50 = diet with a 50:50 FC ratio supplemented with SO $(20 \mathrm{~g} / \mathrm{kg}$ of DM); SO 70:30 = diet with a 70:30 FC ratio supplemented with SO $(20 \mathrm{~g} / \mathrm{kg}$ of DM).

${ }^{2} \mathrm{SED}=$ standard error of the difference.

${ }^{3}$ Atherogenicity index $=[(\mathrm{C} 12: 0+4 \times \mathrm{C} 14: 0+\mathrm{C} 16: 0) /($ monounsaturated FA + polyunsaturated FA $)]$.

$\dagger P<0.10 ;{ }^{*} P<0.05 ;{ }^{* *} P<0.01 ;{ }^{* * *} P<0.001 ; \mathrm{NS}=P>0.10$.

al., 2010a,b). Adding 2\% SO to ewe diets significantly $(P<0.001)$ reduced $(-11 \%)$ palmitic acid, the major FA in milk fat. Despite a greater C16:0 intake by ewes fed the SO-supplemented diets, approximately half of its content in milk fat would be synthesized de novo in the mammary gland, which would probably explain the decrease in milk C16:0 percentages.

The highest forage ration (C 70:30) tended to lower $(P<0.10)$ the atherogenicity index $(\mathbf{A I})$, an indicator for coronary heart disease risk, which was even more pronounced when SO was included in the basal diet $(P$ $<0.001$; Table 3). However, the $\mathrm{SO} \times \mathrm{FC}$ interaction was not significant. In the present study, AI was significantly decreased in milk fat $(-27 \%$ for SO $30: 70$ and $-28 \%$ for SO 50:50 and SO 70:30) by the addition of $2 \% \mathrm{SO}$, which was lower than the decreases obtained by supplementing ewe diets with $6 \%$ soybean oil $(-51 \%$; Gómez-Cortés et al., 2008a). This suggests that the amount of lipid supplement is the most important factor for reducing AI values in milk.

Variations in the FC ratio of the diet altered the respective quantities of most odd- and branched-chain FA in milk (Table 3), which could reflect changes in the rumen bacteria populations. In general, increasing the FC ratio decreases the relative importance of amylolytic bacteria and promotes the growth of cellulolytic bacteria rich in iso FA (Vlaeminck et al., 2006). Thus, higher proportions of forage in the diet resulted in greater concentrations of iso FA in ewe milk, mainly iso $\mathrm{C} 14: 0$ and iso $\mathrm{C} 15: 0(P<0.001)$, as previously described for dairy cows (Vlaeminck et al., 2006). Furthermore, SO supplementation reduced most of the odd- and branched-chain FA (largely derived from bacteria leaving the rumen; Vlaeminck et al., 2006), which is in agreement with previous studies in dairy cows (Rego et al., 2005) and ewes (Hervás et al., 2008; 
trans $(6+7+8) C 18: 1$

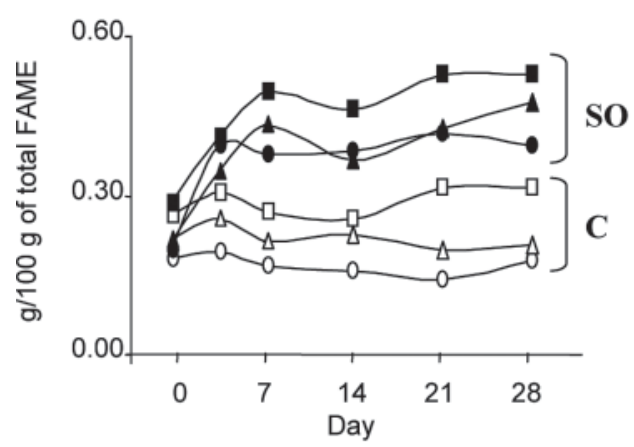

trans-9 C18:1

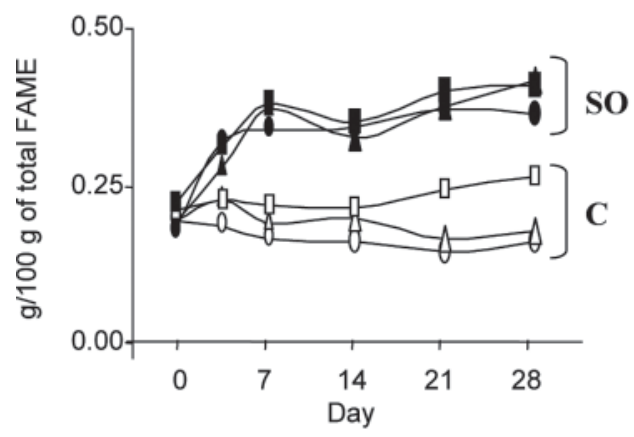

trans-10 C18:1

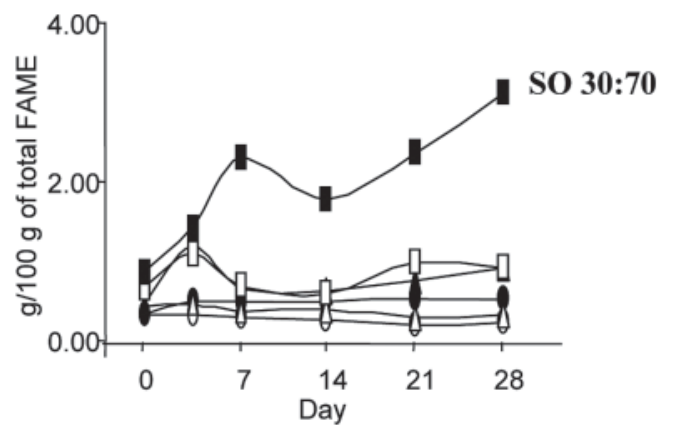

trans-11 C18:1

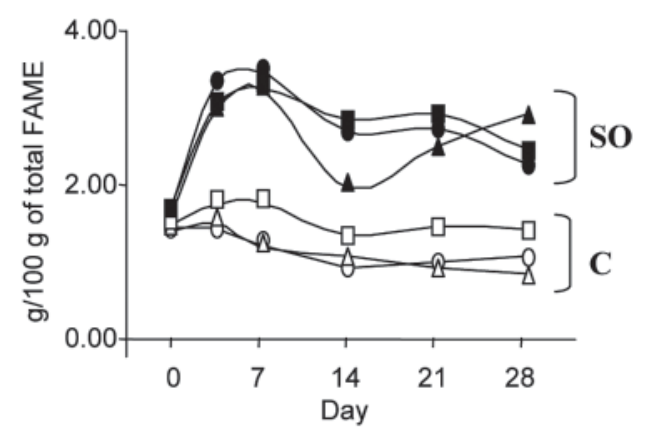

cis-9 trans-11 C18:2

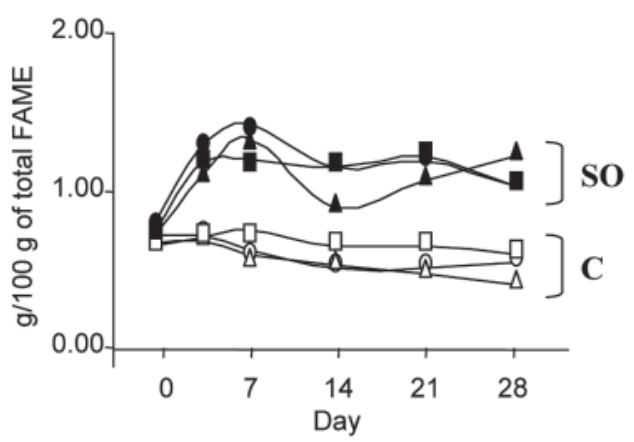

trans-9 cis-11 C18:2

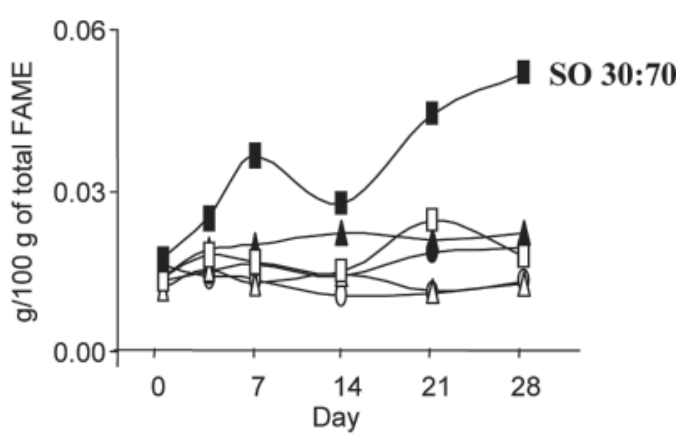

$$
\begin{aligned}
& \text { - C 70:30 - SO 70:30 } \\
& \triangle C \text { 50:50 } ₫ \text { SO 50:50 } \\
& \rightarrow \mathrm{C} 30: 70-\mathrm{SO} 30: 70
\end{aligned}
$$

Figure 1. Temporal changes in trans $(6+7+8) \mathrm{C} 18: 1$, trans-9 C18:1, trans-10 C18:1, trans-11 C18:1, cis-9,trans-11 C18:2, and trans-9,cis-11 $\mathrm{C} 18: 2(\mathrm{~g} / 100 \mathrm{~g}$ of total fatty acid methyl esters) in ewes fed the different experimental rations. C 30:70 = nonsupplemented diet with a 30:70 forage:concentrate (FC) ratio $(\square)$; C 50:50 = nonsupplemented diet with a 50:50 FC ratio $(\Delta)$; C 70:30 = nonsupplemented diet with a 70:30 $\mathrm{FC}$ ratio (O); SO 30:70 = diet with a 30:70 FC ratio supplemented with sunflower oil $(\mathrm{SO} ; 20 \mathrm{~g} / \mathrm{kg}$ of DM) $(\mathbf{\square})$; SO $50: 50=$ diet with a $50: 50$ FC ratio supplemented with $\mathrm{SO}(20 \mathrm{~g} / \mathrm{kg}$ of DM) $(\boldsymbol{\Delta})$; SO 70:30 = diet with a 70:30 FC ratio supplemented with SO (20 g/kg of DM) $(\bullet)$.

Toral et al., 2010a,b) fed SO, and could probably be explained by variations in the rumen bacterial community of the ewes after inclusion of lipid supplements in the diet (Belenguer et al., 2010).
Both the FC ratio and oil supplementation (but mainly the latter) affected C18:0 levels in milk fat (Table 3). Current research indicates that complete biohydrogenation of dietary FA is facilitated by a diet rich 
in forage (Fuentes et al., 2009). The amounts of C18:0 were similar for the $\mathrm{C}$ 50:50 and C 70:30 diets (Table 3 ), whereas the lowest levels were found in $\mathrm{C} 30: 70$ milk and could be attributed to the lower ruminal $\mathrm{pH}$ that occurs after consuming concentrates (Kalscheur et al., 1997). Furthermore, it has been demonstrated in ewes (Kucuk et al., 2001) and steers (Sackmann et al., 2003) that the duodenal flow of C18:0 increased linearly with dietary forage. When $\mathrm{SO}$ was included in the diets, the C18:0 level in milk increased even more $(P<0.001)$, probably as a result of total rumen biohydrogenation of the supplemental unsaturated FA.

\section{Monounsaturated FA}

Significant increases in cis-9 C18:1 $(P<0.001)$ were observed with SO supplementation and high-forage diets (Table 3). Oleic acid enhancement could be a consequence of both the direct incorporation of such FA from diet and the action of the $\Delta^{9}$-desaturase enzyme on C18:0 in the mammary gland.

The oil-supplemented diets resulted in a general increase in trans $\mathrm{C} 18: 1$ isomers $(P<0.001$; Table 3$)$. However, individual isomers varied to a different extent depending on their interaction with a specific diet composition. Changes in the FC ratio hardly modified VA $(P<0.10)$ and in unsupplemented diets, VA showed only a modestly higher value (from 1.16 to $1.54 \%$ ) with the major proportion of concentrate. In contrast, its percentages were doubled with the administration of unprotected SO $(P<0.001$; Table 3$)$. This effect could have been due to the greater presence of linoleic acid in the rations (Table 1). When the rumen functions normally, VA is the main monounsaturated intermediate of linoleic acid metabolism (Harfoot and Hazelwood, 1997). As shown in Figure 1, a different behavior was observed depending on the presence of $\mathrm{SO}$ in the diets, with the trans-11 C18:1 content being more stable but significantly lower in the control than in the SOsupplemented diets.

The effect of the FC ratio was statistically more evident for trans-10 C18:1 $(P<0.001)$ than for VA levels $(P<0.10$; Table 3$)$. Moreover, in contrast to VA, a significant interaction between diet composition and oil supplementation $(P<0.001)$ was observed for trans-10 $\mathrm{C} 18: 1$. Increases in the amount of concentrate in the rations are known to alter ruminal biohydrogenation, causing a shift toward the formation of trans-10 C18:1 at the expense of VA (Piperova et al., 2002; Sackmann et al., 2003). At the same time, the presence of SO is an important factor to consider because this oil contains oleic and linoleic FA, 2 precursors of trans-10 C18:1 in the rumen. In this respect, an interaction between the $\mathrm{FC}$ ratio and $\mathrm{SO}$ resulted in significant increases in trans-10 C18:1 content with the SO 30:70 diet during the whole experimental period $(P<0.001$; Table 3 and Figure 1). Trans-10 C18:1 percentages were doubled by the addition of SO (from 0.49 to $1.07 \%$ ) and more than tripled with the basal diet composition (from 0.37 to $1.40 \%$ ), which would indicate that modifications in the $\mathrm{FC}$ ratio were more effective than the addition of $2 \%$ of SO for switching linoleic acid biohydrogenation pathways.

The levels of other trans C18:1 isomers in milk, such as trans $(6+7+8)$ and trans-9 C18:1 increased with concentrate-rich rations but especially with SO supplementation $(P<0.001$; Table 3 and Figure 1$)$. However, the $\mathrm{SO} \times \mathrm{FC}$ interaction was not significant. Because, according to in vitro (Mosley et al., 2002) and in vivo experiments (Gómez-Cortés et al., 2008b), the principal source of these FA is the extensive biohydrogenation of oleic acid in the rumen, their percentages in ewe milk fat would depend on the proportion of cis-9 C18:1 in the diet (Table 1).

\section{CLA}

The total amount of CLA measured by GC significantly increased in the milk produced by ewes fed SOsupplemented rations $(P<0.001)$ without being influenced by the composition of the basal diet $(P>0.10$, Table 3). The same behavior was observed for the peak containing the predominant CLA isomer, RA, whose levels were multiplied by 1.8 when SO was included in the diets. The limited increases in RA contents in the present study can be explained by the modest addition of SO to the rations ( $2 \%$ of DM). The evolution of RA paralleled that of VA with maintained levels in all control treatments (Figure 1), experiencing a sharp increase during the first week after the incorporation of $\mathrm{SO}$, followed by a slight tendency to reduce its presence in dairy fat. This decrease in the response had previously been reported when different oil levels were added to the rations (Gómez-Cortés et al., 2008a; Toral et al., 2010a,b) and may indicate equilibrium displacement between the 2 biohydrogenation pathways for linoleic acid (Griinari and Bauman, 1999).

Both the oil supplement and FC ratios affected the concentration of trans-9,cis-11 C18:2 in milk fat $(P<$ 0.001; Table 3). Levels of this CLA isomer increased on average from 0.014 to $0.023 \%$ with SO supplementation and from 0.015 to $0.026 \%$ depending on the FC ratio. The changes observed in trans-9,cis-11 C18:2 reflect the same trend as that for trans-10 C18:1, with the SO 30:70 diet producing a prominent increase that reached its highest level at the end of the study period (Figure 1). This effect, together with the close association between them $(\mathrm{r}=0.88 ; P<0.001)$, suggest a 
Table 4. Effect of sunflower oil supplementation (SO), FC ratio of the diet (FC), their interaction $(\mathrm{SO} \times \mathrm{FC})$, and time $(\mathrm{T})$ on milk conjugated linoleic acid $(\mathrm{CLA})$ isomers determined by silver ion HPLC in dairy ewes

CLA isomer

(mg/g of total

fatty acid methyl esters)

\begin{tabular}{|c|c|c|c|c|c|}
\hline & Control & & & suppleme & \\
\hline C $30: 70$ & C 50:50 & C 70:30 & SO $30: 70$ & SO 50:50 & SO $70: 30$ \\
\hline
\end{tabular}

$\mathrm{SED}^{2}$

-

trans-trans

12,14

11,13

10,12

10,12
9,11
8,10
7,9

7,9
6,8

cis-trans and trans-cis

cis-12,trans-14

trans-11,cis-13

trans-10, cis- 12

9,11 (cis-trans + trans-cis)

8,10 (cis-trans + trans-cis)

trans-7, cis-9

0.12

$0.12^{\mathrm{b}}$

C

$0.11^{\mathrm{b}}$

$0.14^{\mathrm{a}} \quad 0.15^{\mathrm{a}}$

$0.007 \quad \mathrm{NS} \quad * * * \quad+* *$

\begin{tabular}{|c|c|c|c|c|c|c|c|c|c|c|}
\hline $0.12^{\mathrm{b}}$ & $0.12^{\mathrm{b}}$ & $0.14^{\mathrm{a}}$ & $0.11^{\mathrm{b}}$ & $0.14^{\mathrm{a}}$ & $0.15^{\mathrm{a}}$ & 0.007 & NS & $* * *$ & $\dagger$ & $* * *$ \\
\hline $0.06^{\mathrm{d}}$ & $0.10^{\mathrm{c}}$ & $0.14^{\mathrm{a}}$ & $0.08^{\mathrm{cd}}$ & $0.12^{\mathrm{b}}$ & $0.15^{\mathrm{a}}$ & 0.009 & $* *$ & $* * *$ & NS & $* *$ \\
\hline $0.04^{\mathrm{b}}$ & $0.03^{\mathrm{b}}$ & $0.03^{\mathrm{b}}$ & $0.06^{\mathrm{a}}$ & $0.06^{\mathrm{a}}$ & $0.06^{\mathrm{a}}$ & 0.004 & $* * *$ & NS & NS & $* * *$ \\
\hline $0.15^{\mathrm{ab}}$ & $0.13^{\mathrm{b}}$ & $0.16^{\mathrm{a}}$ & $0.16^{\mathrm{a}}$ & $0.16^{\mathrm{a}}$ & $0.17^{\mathrm{a}}$ & 0.019 & $* *$ & $*$ & NS & NS \\
\hline $0.01^{\mathrm{c}}$ & $0.01^{\mathrm{c}}$ & $0.01^{\mathrm{c}}$ & $0.02^{\mathrm{b}}$ & $0.02^{\mathrm{b}}$ & $0.03^{\mathrm{a}}$ & 0.002 & $* * *$ & $* * *$ & $* * *$ & NS \\
\hline $0.01^{\mathrm{c}}$ & $0.02^{\mathrm{b}}$ & $0.05^{\mathrm{a}}$ & $0.01^{\mathrm{c}}$ & $0.02^{\mathrm{bc}}$ & $0.04^{\mathrm{a}}$ & 0.005 & NS & $* * *$ & NS & $* * *$ \\
\hline $0.04^{\mathrm{bc}}$ & $0.04^{\mathrm{b}}$ & $0.04^{\mathrm{bc}}$ & $0.04^{\mathrm{c}}$ & $0.05^{\mathrm{a}}$ & $0.05^{\mathrm{a}}$ & 0.002 & $* * *$ & NS & NS & $* * *$ \\
\hline $0.04^{\mathrm{c}}$ & $0.06^{\mathrm{b}}$ & $0.07^{\mathrm{a}}$ & $0.04^{\mathrm{c}}$ & $0.06^{\mathrm{ab}}$ & $0.07^{\mathrm{a}}$ & 0.005 & NS & $* * *$ & NS & NS \\
\hline $0.04^{\mathrm{c}}$ & $0.05^{\mathrm{c}}$ & $0.11^{\mathrm{a}}$ & $0.04^{\mathrm{c}}$ & $0.07^{\mathrm{b}}$ & $0.10^{\mathrm{a}}$ & 0.016 & NS & $* * *$ & $* *$ & $* * *$ \\
\hline $0.05^{\mathrm{b}}$ & $0.03^{\mathrm{d}}$ & $0.02^{\mathrm{d}}$ & $0.10^{\mathrm{a}}$ & $0.05^{\mathrm{bc}}$ & $0.03^{\mathrm{cd}}$ & 0.007 & $* * *$ & $* * *$ & $* * *$ & * \\
\hline $5.95^{\mathrm{b}}$ & $4.79^{\mathrm{b}}$ & $5.40^{\mathrm{b}}$ & $9.39^{\mathrm{a}}$ & $9.86^{\mathrm{a}}$ & $10.16^{\mathrm{a}}$ & 0.766 & $* * *$ & NS & NS & $* *$ \\
\hline $0.17^{\mathrm{b}}$ & $0.15^{\mathrm{b}}$ & $0.17^{\mathrm{b}}$ & $0.21^{\mathrm{a}}$ & $0.23^{\mathrm{a}}$ & $0.23^{\mathrm{a}}$ & 0.012 & $* * *$ & NS & NS & * \\
\hline $0.51^{\mathrm{c}}$ & $0.36^{\mathrm{d}}$ & $0.32^{\mathrm{d}}$ & $0.87^{\mathrm{a}}$ & $0.83^{\mathrm{a}}$ & $0.73^{\mathrm{b}}$ & 0.052 & $* * *$ & $* *$ & NS & NS \\
\hline 0.01 & 0.02 & 0.02 & 0.01 & 0.01 & 0.02 & 0.004 & NS & NS & NS & NS \\
\hline
\end{tabular}

${ }^{\mathrm{a}-\mathrm{d}}$ Means within a row with different superscripts differ significantly.

${ }^{1} \mathrm{C}$ 30:70 = nonsupplemented diet with a 30:70 forage:concentrate $(\mathrm{FC})$ ratio; $\mathrm{C}$ 50:50 = nonsupplemented diet with a 50:50 FC ratio; $\mathrm{C}$ 70:30 = nonsupplemented diet with a 70:30 $\mathrm{FC}$ ratio; $\mathrm{SO} 30: 70=$ diet with a 30:70 FC ratio supplemented with sunflower oil $(\mathrm{SO} ; 20 \mathrm{~g} / \mathrm{kg}$ of DM); SO 50:50 = diet with a 50:50 FC ratio supplemented with SO (20 g/kg of $\mathrm{DM}) ; \mathrm{SO} 70: 30=$ diet with a $70: 30 \mathrm{FC}$ ratio supplemented with SO $(20 \mathrm{~g} / \mathrm{kg}$ of DM).

${ }^{2} \mathrm{SED}=$ standard error of the difference.

$\dagger P<0.10 ;{ }^{*} P<0.05 ;{ }^{* *} P<0.01 ;{ }^{* *} P<0.001 ; \mathrm{NS}=P>0.10$. 
common precursor for both FA as well as alterations in ruminal microbiota and lipid metabolism (Roy et al., 2006; Shingfield et al., 2006).

The levels of trans-10,cis-12 C18:2 obtained by GC in all experimental treatments were negligible and did not permit the observation of any significant modifications $(P>0.10$; Table 3$)$. However, a more detailed examination of the CLA profile by silver ion HPLC did detect some remarkable changes (Table 4). Although trans-10,cis-12 C18:2 contents were always greater in $\mathrm{SO}$ rations $(P<0.001)$, increasing the amount of concentrate also influenced trans-10,cis-12 C18:2 levels, which increased from 0.02 to 0.05 in control diets and from 0.03 to 0.10 in $\mathrm{SO}$ diets $(\mathrm{mg} / \mathrm{g}$ of total FAME; $P<0.001$ ). Moreover, following the same behavior as trans-10 C18:1 and trans-9,cis-11 C18:2, the highest content of trans-10,cis-12 C18:2 was observed in the SO 30:70 treatment. A very similar pattern, reported in ewes fed soybean oil with FC ratios of 75:25 and 60:40 (Antongiovanni et al., 2004; Mele et al., 2006), confirms that the interaction between the supplemental lipid and basal diet composition is of major importance in determining the trans C18:1 and CLA profiles in milk fat.

Silver ion HPLC analysis permitted the determination of trans-7,cis-9 C18:2 levels, quantitatively the second most important CLA isomer in ewe milk. This CLA isomer increased in line with increases in the concentrate and especially if $\mathrm{SO}(P<0.001)$ was present in the rations. Inclusion of $2 \%$ of $\mathrm{SO}$ in the diet also resulted in greater percentages of trans-10,trans-12 and 8-10 (cis-trans + trans-cis) $\mathrm{C} 18: 2$ in ewe milk fat $(P<$ 0.001 ) but these CLA isomers did not depend on the FC ratio $(P>0.10)$, suggesting that their metabolism may only be linked to the linoleic acid supply (SO diets). Conversely, trans-12,trans-14, cis-12,trans-14, and trans-11, cis-13 C18:2 were increased by high-forage rations $(P<0.001)$ as a result of the greater presence of dietary $\alpha$-linolenic acid (Table 1 ). A similar effect was previously reported by Gómez-Cortés et al. (2009) when extruded linseeds, a rich source of $\alpha$-linolenic acid, were added to dairy ewe diets. In the current experiment, these CLA isomers were not affected by the inclusion of SO $(P>0.10)$, which indicates that they are mainly derived from $\alpha$-linolenic acid biohydrogenation and are not dependent on linoleic acid intake.

\section{CONCLUSIONS}

Sunflower oil supplementation and FC ratios of dairy ewe diets affected their milk yield, although differences between treatments were small, probably because the high intake levels (slightly increased with the addition of SO) could have contributed to improving the potential milk production capability in all ewes. With regard to the milk FA profile, changes in the FC ratio cause far fewer alterations than the addition of $2 \%$ SO. However, diet composition seems to be critical for switching linoleic acid biohydrogenation pathways. Supplementing a high-concentrate ration with low levels of SO (SO 30:70) enhanced the trans-10 C18:1, trans-9,cis-11 C18:2, and trans-10,cis-12 C18:2 contents in milk fat, probably due to changes in rumen microbiota. In contrast, the FC ratio had hardly any effect on VA and RA, but their percentages were almost doubled by lipid supplementation. The present research confirms that limited addition of SO in a low- to moderate-concentrate diet is an advisable nutritional strategy to obtain milk enriched in CLA and with a reduced AI.

\section{ACKNOWLEDGMENTS}

This work was supported by the Ministerio de Ciencia e Innovación (MICINN; AGL2008-04805). The authors from the Instituto del Frío (CSIC) thank the Comunidad Autónoma de Madrid (S2009-AGR-1469) and the Ministerio de Ciencia e Innovación (Consolider Ingenio 2010 Programme; FUN-C-FOOD CSD2007-063) for their financial support. They thank M. V. RodríguezPino (CSIC, Madrid, Spain) for her inestimable technical assistance in the chromatographic analysis. The authors from the Instituto de Ganadería de Montaña (León, Spain) thank the research farm staff for their help in the fieldwork. P. G. Toral was granted a fellowship from the CSIC (I3P Programme).

\section{REFERENCES}

Antongiovanni, M., M. Mele, A. Buccioni, F. Petacchi, A. Serra, M. P. Melis, L. Cordeddu, S. Banni, and P. Secchiari. 2004. Effect of forage/concentrate ratio and oil supplementation on C18:1 and CLA isomers in milk fat from Sarda ewes. J. Anim. Feed Sci. 13:669-672.

AOCS. 2008. Official Methods and Recommended Practices of the American Oil Chemist's Society. 5th ed. (2nd printing). AOCS, Urbana, IL.

Bargo, F., J. E. Delahoy, G. F. Schroeder, and L. D. Muller. 2006. Milk fatty acid composition of dairy cows grazing at two pasture allowances and supplemented with different levels and sources of concentrate. Anim. Feed Sci. Technol. 125:17-31.

Belenguer, A., P. G. Toral, P. Frutos, and G. Hervás. 2010. Changes in the rumen bacterial community in response to sunflower oil and fish oil supplements in the diet of dairy sheep. J. Dairy Sci. 93:3275-3286.

Bocquier, F., and G. Caja. 2001. Effects of nutrition on ewes' milk quality. Prod. Anim. 14:129-140.

Chilliard, Y., and A. Ferlay. 2004. Dietary lipids and forages interactions on cow and goat milk fatty acid composition and sensory properties. Reprod. Nutr. Dev. 44:467-492.

Chilliard, Y., A. Ferlay, J. Rouel, and G. Lamberet. 2003. A review of nutritional and physiological factors affecting goat milk lipid synthesis and lipolysis. J. Dairy Sci. 86:1751-1770.

Chilliard, Y., F. Glasser, A. Ferlay, L. Bernard, J. Rouel, and M. Doreau. 2007. Diet, rumen biohydrogenation and nutritional quality of cow and goat milk fat. Eur. J. Lipid Sci. Technol. 109:828855 . 
Doreau, M., Y. Chilliard, H. Rulquin, and D. I. Demeyer. 1999. Manipulation of milk fat in dairy cows. Pages 81-109 in Recent Advances in Animal Nutrition. P. C. Garnsworthy, and J. Wiseman, ed. Nottingham Press, Nottingham, UK.

Fuentes, M. C., S. Calsamiglia, P. W. Cardozo, and B. Vlaeminck. 2009. Effect of $\mathrm{pH}$ and level of concentrate in the diet on the production of biohydrogenation intermediates in a dual-flow continuous culture. J. Dairy Sci. 92:4456-4466.

Gómez-Cortés, P., A. Bach, P. Luna, M. Juárez, and M. A. de la Fuente. 2009. Extruded linseed on ewes rations improves omega-3 fatty acids and conjugated linoleic acid contents in cheese and milk fat. J. Dairy Sci. 92:4122-4134.

Gómez-Cortés, P., P. Frutos, A. R. Mantecón, M. Juárez, M. A. de la Fuente, and G. Hervás. 2008b. Addition of olive oil to dairy ewe diet: Effect on milk fatty acid profile and animal performance. J. Dairy Sci. 91:3119-3127.

Gómez-Cortés, P., G. Hervás, A. R. Mantecón, M. Juárez, M. A. de la Fuente, and P. Frutos. 2008a. Milk production, CLA content and in vitro ruminal fermentation in response to high levels of soybean oil in dairy ewe diet. J. Dairy Sci. 91:1560-1569.

Griinari, J. M., and D. E. Bauman. 1999. Biosynthesis of conjugated linoleic acid and its incorporation into meat and milk in ruminants. Pages 180-200 in Advances in CLA Research, Volume 1. M. P. Yurawecz, M. M. Mossoba, J. K. G. Kramer, M. W. Pariza, and G. J. Nelson, ed. AOCS Press, Champaign, IL.

Harfoot, C. G., and G. P. Hazelwood. 1997. Lipid metabolism in the rumen. Pages 382-426 in The Rumen Microbial Ecosystem. P. M. Hobson, ed. Elsevier, New York, NY.

Hervás, G., P. Luna, A. R. Mantecón, N. Castañares, M. A. de la Fuente, M. Juárez, and P. Frutos. 2008. Effect of diet supplementation with sunflower oil in milk production, fatty acid profile and ruminal fermentation in lactating ewes. J. Dairy Res. 75:399-405.

ISO. 1999a. Animal feeding stuffs-Determination of moisture and other volatile matter content. International Standard ISO 6496:1999. International Organization for Standardization (ISO), Geneva, Switzerland.

ISO. 1999b. Whole milk-Determination of milkfat, protein and lactose content-Guidance on the operation of mid-infrared instruments. International Standard ISO 9622:1999. International Organization for Standardization (ISO), Geneva, Switzerland.

ISO. 2002a. Animal feeding stuffs - Determination of crude ash. International Standard ISO 5984:2002. International Organization for Standardization (ISO), Geneva, Switzerland.

ISO. 2002b. Milk fat-Preparation of fatty acid methyl esters. International Standard ISO 15884:2002. International Organization for Standardization (ISO), Geneva, Switzerland.

ISO. 2005. Animal feeding stuffs-Determination of nitrogen content and calculation of crude protein content-Part 2: Block digestion and steam distillation method. International Standard ISO 59832:2005. International Organization for Standardization (ISO), Geneva, Switzerland.

Kalscheur, K. F., B. B. Teter, L. S. Piperova, and R. A. Erdman. 1997. Effect of dietary forage concentration and buffer addition on duodenal flow of trans-C18:1 fatty acids and milk fat production in dairy cows. J. Dairy Sci. 80:2104-2114.

Kucuk, O., B. W. Hess, P. A. Ludden, and D. C. Rule. 2001. Effect of forage:concentrate ratio on ruminal digestion and duodenal flow of fatty acids in ewes. J. Anim. Sci. 79:2233-2240.

Lock, A. L., J. Kraft, B. H. Rice, and D. E. Bauman. 2009. Biosynthesis and biological activity of rumenic acid: A natural CLA isomer. Pages 195-230 in Trans Fatty Acids in Human Nutrition. F. Destaillats, J. L. Sébédio, F. Dionisi, and J. M. Chardigny, ed. The Oily Press, Bridgwater, UK.

Luna, P., M. Juárez, and M. A. de la Fuente. 2005. Validation of a rapid milk fat separation method to determine the fatty acid profile by gas chromatography. J. Dairy Sci. 88:3377-3381.

Martini, M., G. B. Liponi, and F. Salari. 2010. Effect of forage:concentrate ratio on the quality of ewe's milk, especially on milk fat globules characteristics and fatty acids composition. J. Dairy Res. 77:239-244.

Mele, M., A. Buccioni, F. Petacchi, A. Serra, S. Banni, M. Antongiovanni, and P. Secchiari. 2006. Effect of forage/concentrate ratio and soybean oil supplementation on milk yield, and composition from Sarda ewes. Anim. Res. 55:273-285.

Milán, M. J., G. Caja, R. González-González, A. M. Fernández-Pérez, and X. Such. 2011. Structure and performance of Awassi and Assaf dairy sheep farms in northwestern Spain. J. Dairy Sci. 94:771784 .

Mosley, E. E., G. L. Powell, M. B. Riley, and T. C. Jenkins. 2002. Microbial biohydrogenation of oleic acid to trans isomers in vitro. J. Lipid Res. 43:290-296.

Palmquist, D. L., A. L. Lock, K. J. Shingfield, and D. E. Bauman. 2005. Biosynthesis of conjugated linoleic acid in ruminants and humans. Pages 179-217 in Advances in Food and Nutrition Research. Vol. 50. S. L. Taylor, ed. Elsevier Academic Press, San Diego, CA.

Piperova, L. S., J. Sampugna, B. B. Teter, K. F. Kalscheur, M. P. Yurawecz, Y. Ku, K. M. Morehouse, and R. A. Erdman. 2002. Duodenal and milk trans octadecenoic acid and conjugated linoleic acid (CLA) isomers indicate that postabsorptive synthesis is the predominant source of cis-9-containing CLA in lactating dairy cows. J. Nutr. 132:1235-1241.

Pulina, G., A. Nudda, G. Battacone, and A. Cannas. 2006. Effects of nutrition on the contents of fat, protein, somatic cells, aromatic compounds, and undesirable substances in sheep milk. Anim. Feed Sci. Technol. 131:255-291.

Rego, O. A., H. J. D. Rosa, P. V. Portugal, T. Franco, C. M. Vouzela, A. E. S. Borba, and R. J. B. Bessa. 2005. The effects of supplementation with sunflower and soybean oils on the fatty acid profile of milk fat from grazing dairy cows. Anim. Res. 54:17-24.

Roy, A., A. Ferlay, K. J. Shingfield, and Y. Chilliard. 2006. Examination of the persistency of milk fatty acid composition responses to plant oils in cows given different basal diets, with particular emphasis on trans-C18:1 fatty acids and isomers of conjugated linoleic acid. Anim. Sci. 82:479-492.

Sackmann, J. R., S. K. Duckett, M. H. Gillis, C. E. Realini, A. H. Parks, and R. B. Eggelston. 2003. Effects of forage and sunflower oil levels on ruminal biohydrogenation of fatty acids and conjugated linoleic acid formation in beef steers fed finishing diets. J. Anim. Sci. 81:3174-3181.

Sanz-Sampelayo, R., Y. Chilliard, P. Schmidely, and J. Boza. 2007. Influence of type of diet on the fat constituents of goat and sheep milk. Small Rumin. Res. 68:42-67.

Shingfield, K. J., Y. Chilliard, V. Toivonen, P. Kairenius, and D. I. Givens. 2008. Trans fatty acids and bioactive lipids in ruminant milk. Adv. Exp. Med. Biol. 606:3-65.

Shingfield, K. J., C. K. Reynolds, G. Hervás, J. M. Griinari, A. S. Grandison, and D. E. Beever. 2006. Examination of the persistency of milk fatty acid composition responses to fish oil and sunflower oil in the diet of dairy cows. J. Dairy Sci. 89:714-732.

Toral, P. G., G. Hervás, P. Gómez-Cortés, P. Frutos, M. Juárez, and M. A. de la Fuente. 2010a. Milk fatty acid profile and dairy sheep performance in response to diet supplementation with sunflower oil plus incremental levels of marine algae. J. Dairy Sci. 93:16551667.

Toral, P. G., P. Frutos, G. Hervás, P. Gómez-Cortés, M. Juárez, and M. A. de la Fuente. 2010b. Changes in milk fatty acid profile and animal performance in response to fish oil supplementation, alone or in combination with sunflower oil, in dairy ewes. J. Dairy Sci. 93:1604-1615.

Tsiplakou, E., and G. Zervas. 2008. Comparative study between sheep and goats on rumenic acid and vaccenic acid in milk fat under the same dietary treatments. Livest. Sci. 119:87-94.

Vlaeminck, B., V. Fievez, A. R. J. Cabrita, A. J. M. Fonseca, and R. J. Dewhurst. 2006. Factors affecting odd- and branched-chain fatty acids in milk: A review. Anim. Feed Sci. Technol. 131:389-417. 